\title{
Effect of mid-term drought on Quercus pubescens BVOCs' emission seasonality and their dependency on light and/or temperature
}

\author{
Amélie Saunier $^{1}$, Elena Ormeño ${ }^{1}$, Christophe Boissard $^{2}$, Henri Wortham $^{3}$, Brice Temime-Roussel ${ }^{3}$, \\ Caroline Lecareux ${ }^{1}$, Alexandre Armengaud ${ }^{4}$, and Catherine Fernandez ${ }^{1}$ \\ ${ }^{1}$ Aix Marseille Univ., Univ Avignon, CNRS, IRD, IMBE, Marseille, France \\ ${ }^{2}$ Laboratoire des Sciences du Climat et de l'Environnement, LSCE/IPSL, CEA-CNRS-UVSQ, Université Paris-Saclay, \\ 91191 Gif-sur-Yvette, France \\ ${ }^{3}$ Aix Marseille Univ., CNRS, LCE, Laboratoire de Chimie de l'Environnement, Marseille, France \\ ${ }^{4}$ Air PACA, 146 rue Paradis, Bâtiment Le Noilly Paradis, 13294 Marseille, CEDEX 06, France \\ Correspondence to: Amélie Saunier (amelie.saunier@imbe.fr)
}

Received: 19 September 2016 - Discussion started: 7 October 2016

Revised: 11 May 2017 - Accepted: 22 May 2017 - Published: 22 June 2017

\begin{abstract}
Biogenic volatile organic compounds (BVOCs) emitted by plants represent a large source of carbon compounds released into the atmosphere, where they account for precursors of tropospheric ozone and secondary organic aerosols. Being directly involved in air pollution and indirectly in climate change, understanding what factors drive BVOC emissions is a prerequisite for modeling their emissions and predict air pollution. The main algorithms currently used to model BVOC emissions are mainly light and/or temperature dependent. Additional factors such as seasonality and drought also influence isoprene emissions, especially in the Mediterranean region, which is characterized by a rather long drought period in summer. These factors are increasingly included in models but only for the principal studied BVOC, namely isoprene, but there are still some discrepancies in estimations of emissions. In this study, the main BVOCs emitted by Quercus pubescens - isoprene, methanol, acetone, acetaldehyde, formaldehyde, MACR, MVK and ISOPOOH (these three last compounds detected under the same $m / z$ ) - were monitored with a PTR-ToF-MS over an entire seasonal cycle during both in situ natural and amplified drought, which is expected with climate change. Amplified drought impacted all studied BVOCs by reducing emissions in spring and summer while increasing emissions in autumn. All six BVOCs monitored showed daytime light and temperature dependencies while three BVOCs (methanol, acetone and formaldehyde) also showed emissions during the night despite the absence of light under constant tempera-
\end{abstract}

ture. Moreover, methanol and acetaldehyde burst in the early morning and formaldehyde deposition and uptake were also punctually observed, which were not assessed by the classical temperature and light models.

\section{Introduction}

Plants contribute to global emissions of volatile organic compounds (VOCs) with an estimated emission rate of $10^{15} \mathrm{gC} \mathrm{yr}^{-1}$ (Guenther et al., 1995; Harrison et al., 2013). The large variety of compounds released by plants represents, at the global scale, $2-3 \%$ of the total carbon released in the atmosphere (Kesselmeier and Staudt, 1999). Under strong photochemical conditions, biogenic volatile organic compounds (BVOCs), together with $\mathrm{NO}_{x}$, can significantly contribute to tropospheric ozone concentration (Xie et al., 2008; Papiez et al., 2009). In addition to its greenhouse effect, $\mathrm{O}_{3}$ has strong effects on plant metabolism (ReigArmiñana et al., 2004; Beauchamp et al., 2005) as well as on human health (Lippmann, 1989). BVOCs are also rapidly oxidized by $\mathrm{OH}$ radical and $\mathrm{NO}_{3}$ (Hallquist et al., 2009; Liu et al., 2012), which account for an important fraction of the total mass of secondary organic aerosols (SOA; Jimenez et al., 2009). Methanol and acetone are, after isoprene, the principal BVOCs released to the atmosphere. Isoprene emissions represent between 400 and $600 \mathrm{TgC} \mathrm{yr}^{-1}$ at the global scale (Arneth et al., 2008) whereas methanol emissions vary be- 
tween 75 and $280 \mathrm{TgC} \mathrm{yr}^{-1}$ (Singh et al., 2000; Heikes et al., 2002, respectively) and acetone emissions represent only $33 \mathrm{TgC} \mathrm{yr}^{-1}$ (Jacob et al., 2002). Other compounds such as acetaldehyde, methacrolein (MACR), methyl vinyl ketone (MVK), isoprene hydroxy hydroperoxides (ISOPOOH) and formaldehyde, whose biogenic origin has been poorly investigated, are better known to be anthropogenic and/or secondary VOCs issued from atmospheric oxidations (Hallquist et al., 2009). However, acetaldehyde is also a by-product of plant metabolism and its emissions represent $23 \mathrm{Tg} \mathrm{yr}^{-1}$ at the global scale (Millet et al., 2010). Formaldehyde, MACR, MVK and ISOPOOH are released by plants through oxidations of methanol and isoprene, respectively, within leaves but they can have other leaf precursors (Oikawa and Lerdau, 2013). Thus, it is thereby important to model all BVOC emissions with the aim of predicting their effect on secondary atmospheric chemistry.

Current models allow us to predict BVOC emissions according to the type of vegetation, biomass density, leaf age, specific emission factor for many vegetal species, as well as the impact of some environmental factors. Models, such as the MEGAN (Guenther et al., 2006, 2012) or CHIMERE (Menut et al., 2013), include at least two main algorithms that allow us to model light and temperature emission dependence (called $L+T$ algorithm afterwards) and a temperature dependence algorithm (called $T$ algorithm afterwards), both described in Guenther et al. (1995). The $L+T$ algorithm is typically used for BVOC emissions whose synthesis rapidly relies on photosynthesis and hence include de novo emissions. The $T$ algorithm is used for BVOC emissions that do not directly rely on BVOC synthesis when, for example, they originate from permanent large storage pools (Ormeno et al., 2011). The dependency on light and/or temperature is well documented for isoprenoids (Owen et al., 2002; Rinne et al., 2002; Dindorf et al., 2006) but there is still a lack of knowledge about highly volatile BVOCs (e.g., methanol, acetone, acetaldehyde). However, many of these compounds are very reactive in the atmosphere (Hallquist et al., 2009) and could be emitted in large quantities into the atmosphere at global scale. The characterization of their emissions and sensitivity to light and/or temperature is, thus, necessary in order to obtain reliable predictions of atmospheric processes in order to not miss this important part of the atmospheric reactivity.

Other factors than light and temperature can drive BVOC emissions, such as water stress. Most studies dealing with BVOC response to water stress have, however, focused on terpene-like compounds and have been carried out after weeks of watering restriction or removal under controlled conditions (for a review, see studies cited in Peñuelas and Staudt, 2010). Considerable uncertainty remains in our understanding of emission mechanisms since some works showed increases (Funk et al., 2004; Monson et al., 2007) or decreases of isoprene emissions (Brüggemann and Schnitzler, 2002; Fortunati et al., 2008) and there is a lack of knowledge of the impact of water stress on highly volatile BVOC emissions (e.g., methanol). Moreover, the understanding of isoprene sensitivity and highly volatile BVOCs to recurrent water stress (few years) under in situ conditions is clearly missing. Likewise, the capacity of current $L+T$ and $T$ algorithms to predict emission shifts under different drought scenarios in the context of climate change needs to be addressed for isoprene and highly volatile compounds. This is of particular interest for the Mediterranean area where the most severe climatic scenario of the IPCC predicts an intensification of summer drought consisting of a rain reduction that could locally reach $30 \%$, an extension of the drought period as well as a temperature rise of $3.4^{\circ} \mathrm{C}$ (Giorgi and Lionello, 2008; IPCC, 2013; Polade et al., 2014) for 2100.

In the present investigation, we aimed (i) to study the emission factors of each studied BVOC released by $Q$. pubescens, including isoprene and highly volatile compounds that originate from plant metabolism under water stress, and (ii) to test the performance of the $L+T$ and $T$ algorithms to predict isoprene and highly volatile BVOC emissions over the seasonal cycle and under two recurrent water stress treatments. $Q$. pubescens was chosen as the vegetal model because this species is highly resistant to drought and widespread in the northern Mediterranean area, occupying 2 million ha (Quézel and Médail, 2003). It also represents the major source of isoprene emissions in the Mediterranean area and the second major source on the European scale (Keenan et al., 2009).

\section{Material and methods}

\subsection{Experimental site}

Our study was performed at the $\mathrm{O}_{3} \mathrm{HP}$ site (Oak Observatory at the Observatoire de Haute Provence), located $60 \mathrm{~km}$ North of Marseille, France $\left(5^{\circ} 42^{\prime} 44^{\prime \prime}\right.$ E, $\left.43^{\circ} 55^{\prime} 54^{\prime \prime} \mathrm{N}\right)$, at an elevation of $650 \mathrm{~m}$ above the sea level. The $\mathrm{O}_{3} \mathrm{HP}\left(955 \mathrm{~m}^{2}\right)$, free from direct human disturbance for 70 years, is a homogeneous forest mainly composed of $Q$. pubescens $(\approx 90 \%$ of the biomass and $\approx 75 \%$ of the trees) with a mean diameter of $1.3 \mathrm{~m}$. The remaining $10 \%$ of the biomass is mostly represented by Acer monspessulanum trees, a very low isopreneemitter species (Genard-Zielinski et al., 2015). The $\mathrm{O}_{3} \mathrm{HP}$ site was created in 2009 in order to study the impact of climate change on a $Q$. pubescens forest. Using a rainfall exclusion device (an automated monitored roof deployed during chosen rain events) set up over part of the $\mathrm{O}_{3} \mathrm{HP}$ canopy, it was possible to reduce natural rain by $30 \%$ and to extend the drought period in an attempt to mimic the current climatic model projections for 2100 (Giorgi and Lionello, 2008; IPCC, 2013; Polade et al., 2014). Two plots were considered in the site: a plot receiving natural precipitation where trees grew under natural drought $\left(300 \mathrm{~m}^{2}\right.$ surface, used as control plot) and a second plot submitted to amplified drought $\left(232 \mathrm{~m}^{2}\right.$ surface). Rain exclusion on this latter plot started in May 2012 and was continuously applied every year, princi- 


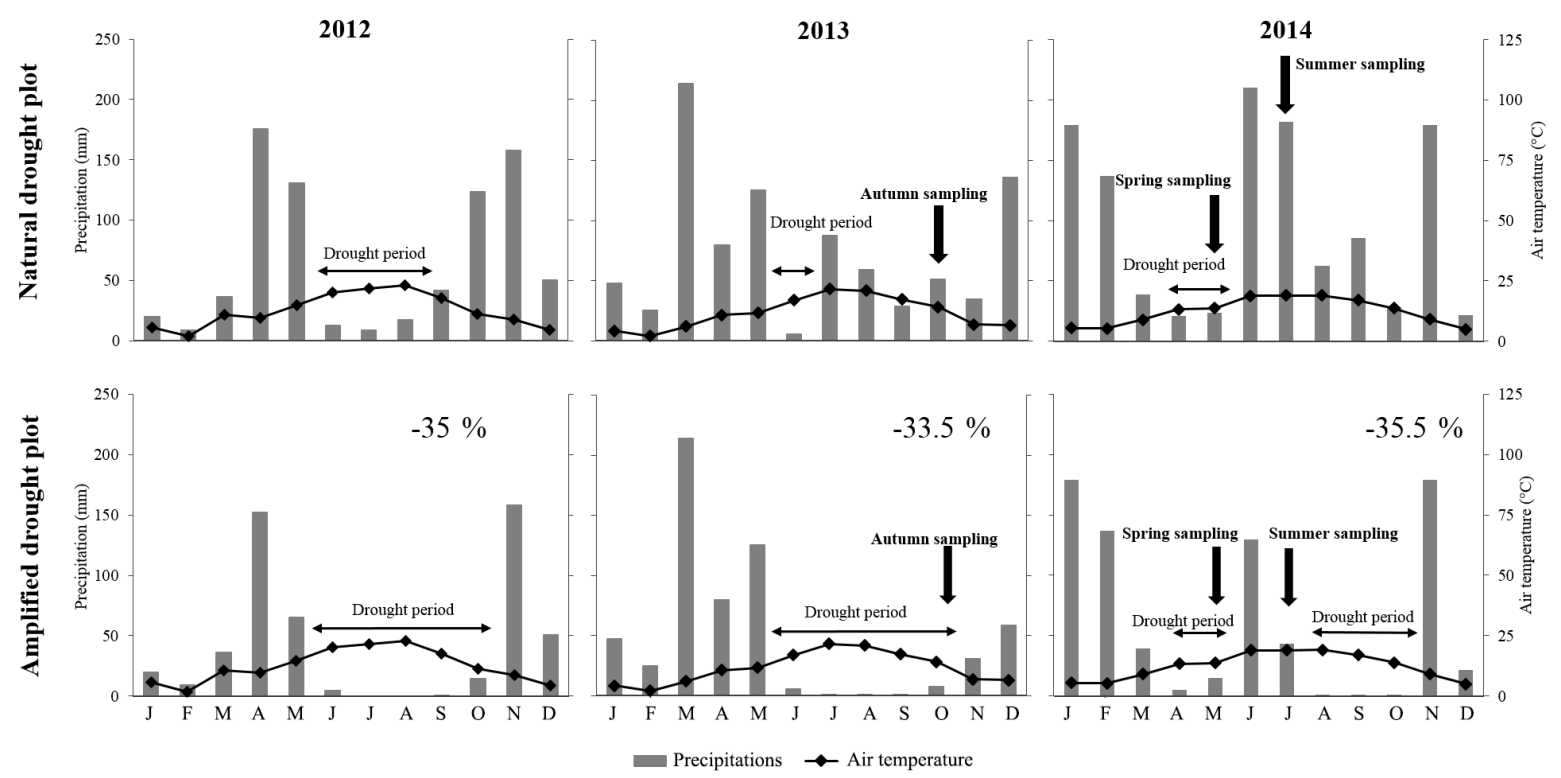

Figure 1. Ombrothermic diagram for natural and amplified drought in 2012, 2013 and 2014. Bars represent mean monthly precipitation $(\mathrm{mm})$ and curves represent mean monthly temperature $\left({ }^{\circ} \mathrm{C}\right)$. On each amplified drought graph, the percentage represents the proportion of excluded rain compared to the natural drought plot.

pally during the growth period. Ombrothermic diagrams indicate that the drought period was extended for 2 months in 2012, 4 months in 2013 and 3 months in 2014 for amplified drought relative to natural drought (Fig. 1). Data on cumulative precipitation show that $35 \%$ of rain was excluded in 2012 (from 29 April from to 27 October), $33.5 \%$ in 2013 (from 7 July from to 29 December) and $35.5 \%$ in 2014 (from 8 April to 8 December). This experimental setup involved a recurrent drought in the amplified drought plot. Sampling was performed at the branch scale at the top of the canopy during three campaigns from October 2013 to July 2014, covering an entire seasonal cycle: in autumn (14 to 28 October 2013, second year of amplified drought), in spring (12 to 19 May 2014, third year of amplified drought) and in summer (13 to 25 July 2014, third year of amplified drought). Spring, summer and autumn campaigns corresponded to the end of leaf growth, leaf maturation and the beginning of the leaf senescence, respectively. The same five trees per plot were selected and investigated throughout the study.

\subsection{Branch scale-sampling methods}

Two identical dynamic branch enclosures were used for sampling gas exchange (in terms of $\mathrm{CO}_{2}, \mathrm{H}_{2} \mathrm{O}$ and BVOCs) as fully described in Genard-Zielinski et al. (2015) with some modifications. Branches were enclosed in $\mathrm{a} \approx 30 \mathrm{~L}$ PTFE (polytetrafluoroethylene) frame closed by a $50 \mu \mathrm{m}$ thick PTFE film. One tree from a natural and one tree from an amplified drought plot were analyzed concomitantly during 1 or 2 days. Inlet air was introduced at $9 \mathrm{~L} \mathrm{~min}^{-1}$, controlled by mass flow controllers (MFC, Bronkhorst), using a pump lined with PTFE (KNF N840.1.2FT.18 ${ }^{\circledR}$, Germany) allowing for air renewal inside the chamber every $\sim 3 \mathrm{~min}$. Ozone was removed from inlet air by placing PTFE filters impregnated with sodium thiosulfate $\left(\mathrm{Na}_{2} \mathrm{~S}_{2} \mathrm{O}_{3}\right)$ as described by Pollmann et al. (2005), so that oxidation of BVOCs due to ozone within the enclosed atmosphere is negligible. The excess of air humidity was removed using Drierite. A PTFE fan ensured a rapid mixing of the chamber air and a slight positive pressure within the enclosure enabled the PTFE film to be held away from leaves to minimize biomass damage. Microclimate (temperature, relative humidity and photosynthetically active radiation or PAR) was continuously (every minute) monitored by a data logger (LI-COR $1400^{\circledR}$; Lincoln, NE, USA) with a relative humidity and temperature probe placed inside the chamber (RHT probe, HMP60, Vaisala, Finland) and a quantum sensor (PAR, LI-COR, PAR-SA $190^{\circledR}$, Lincoln, NE, USA) placed outside the chamber. The climatic conditions in terms of PAR and temperatures are summarized in Fig. S1 (in the Supplement) for each field campaigns. All air flow rates were controlled by MFC and all tubing lines were made of PTFE. Chambers were installed the day before measurements and flushed overnight. Enclosed branches contained 8 to 12 leaves corresponding to a range of 1.4 to $3.6 \mathrm{~g}$ of dry matter and 110 to $320 \mathrm{~cm}^{2}$ of leaf surface, respectively.

\subsection{Ecophysiological parameters}

Exchange of $\mathrm{CO}_{2}$ and $\mathrm{H}_{2} \mathrm{O}$ from the enclosed branches was continuously (every minute) measured using infrared gas analyzers (IRGA $840 \mathrm{~A}^{\circledR}$, LI-COR) concomitantly with BVOC 
emission measurements (see Sect. 2.4). Gas exchange values were averaged by taking into account all the data measured between 12:00 and 15:00 (local time). Net photosynthesis $\left(\mathrm{Pn}, \mu \mathrm{molCO} \mathrm{C}_{2} \mathrm{~m}^{-2} \mathrm{~s}^{-1}\right)$ and stomatal conductance to water $\left(\mathrm{Gw}, \mathrm{mmolH}_{2} \mathrm{O} \mathrm{m}^{-2} \mathrm{~s}^{-1}\right)$ were calculated using equations described by Von Caemmerer and Farquhar (1981) as used in Genard-Zielinski et al. (2015) (for more details, see Appendix A, Eqs. A1 to A4). Leaves from enclosed branches were directly collected after gas exchange sampling to accurately measure leaf surface with a leaf area meter. Pn and $\mathrm{Gw}$ were hence expressed in a leaf surface basis. After that, leaves were freeze-dried to assess their dry mass.

\subsection{BVOC analysis}

A PTR-ToF-MS 8000 instrument (Ionicon Analytik GmbH, Innsbruck, Austria) was used for online measurements of BVOCs emitted by the enclosed branches. A multi-position common outlet flow path selector valve system (Vici) and a vacuum pump were used to sequentially select air samples from: amplified drought, inlet air, natural drought, ambient air and catalyst. The catalyst consists in a $25 \mathrm{~cm}$ long stainless steel tubing, filled with platinum wool and heated at $350{ }^{\circ} \mathrm{C}$ to efficiently remove VOCs from sample and measure potential instrumental background levels. Each sample was analyzed every hour, with $15 \mathrm{~min}$ of analysis. Mass spectra in the range $0-500 \mathrm{amu}$ were recorded at $1 \mathrm{~min}$ integration time. The reaction chamber pressure was fixed at $2.1 \mathrm{mbar}$, the drift tube voltage at $550 \mathrm{~V}$ and the drift tube temperature at $313 \mathrm{~K}$, corresponding to an electric field strength applied to the drift tube $(E)$ to a buffer gas density $(N)$ ratio of $125 \mathrm{Td}\left(1 \mathrm{Td}=10^{-17} \mathrm{~V} \mathrm{~cm}^{2}\right)$. A calibration gas standard, consisting of a mixture of 14 aromatic organic compounds (TO-14A Aromatic Mix, Restek Corporation, Bellefonte, USA, $100 \pm 10 \mathrm{ppb}$ in Nitrogen), was used to experimentally determine the ion relative transmission efficiency. BVOCs targeted in this study and their corresponding ions include formaldehyde $(\mathrm{m} / z 31.018)$, methanol $(\mathrm{m} / \mathrm{z} 33.033)$, acetaldehyde $(m / z 45.03)$, acetone $(m / z 59.05)$, isoprene $(\mathrm{m} / z 41.038,69.069)$ and MACR + MVK + ISOPOOH $(\mathrm{m} / z$ 71.049; these three compounds were detected with the same $m / z$ with PTR-MS). The signal corresponding to protonated VOCs was converted into mixing ratios by using the proton transfer rate constants $k$ given by Cappellin et al. (2012). Formaldehyde concentrations were calculated according to the method described by Vlasenko et al. (2010) to account for its humidity-dependent sensitivity.

BVOC emission rates (ER) were calculated by considering the BVOC concentrations in the inlet and outlet air as follows (Eq. 1):

$\mathrm{ER}=\frac{Q_{0} \times\left(C_{\mathrm{out}}-C_{\mathrm{in}},\right)}{B}$

where ER was expressed in $\mu \mathrm{gCg} \mathrm{g}_{\mathrm{DM}}^{-1} \mathrm{~h}^{-1}, Q_{0}$ was the flow rate of the air introduced into the chamber $\left(\mathrm{Lh}^{-1}\right), C_{\text {out }}$ and
$C_{\text {in }}$ were the concentrations in the inflowing and outflowing air $\left(\mu \mathrm{gC} \mathrm{L}^{-1}\right)$, respectively, and $B$ was the total dry biomass matter $\left(g_{\text {DM }}\right)$. Daily cycles were made by averaging measured emissions of all trees every hour.

\subsection{Emission algorithms}

The light and temperature dependency of $Q$. pubescens BVOCs (isoprene and highly volatile compounds) under natural and amplified drought was tested using both the $L+T$ and $T$ algorithms. Emission rates calculated according to these algorithms (afterwards, called $\mathrm{ER}_{L+T}$ and $\mathrm{ER}_{T}$, respectively) were calculated using the equations described in Guenther et al. (1995) (for more details, see Appendix B, Eqs. B1 to B5). The empirical coefficient $\beta$ (used in the $T$ algorithm) was determined for each compound according to the season and the treatment through the slope of correlation between the natural logarithm of emission rates (measured emissions, $\mu \mathrm{gCg} \mathrm{g}_{\mathrm{DM}}^{-1} \mathrm{~h}^{-1}$ ) and experimental temperature $(\mathrm{K})$. Emission factors (EF), which are emission rates at standard conditions of light and temperature $\left(1000 \mu \mathrm{mol} \mathrm{m}^{-2} \mathrm{~s}^{-1}\right.$ and $30^{\circ} \mathrm{C}$ ), were used to calculate modeled emissions and were determined for each compound under each season and treatment tree by tree. EF values correspond to the slope of the correlation between experimental emission rates and $C_{l} \times C_{t}$ when using the $L+T$ algorithm or $C_{T}$ when using the $T$ algorithm (without forcing data to pass through the origin; see Appendix B for a full description of $C_{l} \cdot C_{t}$ and $C_{T}$ ). $R^{2}$ and $p$ values of these correlations tree by tree are presented in Tables S1-S6 (Supplement) and all parameters used for the calculation of modeled emissions are presented in Tables S7 and $\mathrm{S} 8$ (for $C_{l} \cdot C_{t}$ and $C_{T}$, respectively, in the Supplement).

\subsection{Data treatment}

Data treatment was performed with the software STATGRAPHICS $^{\circledR}$ centurion XV (Statpoint, Inc). After having checked the normality of the data set, two-way repeated measures ANOVA was carried out to evaluate the variability of $\mathrm{Pn}, \mathrm{Gw}$ and $\mathrm{BVOC}$ emission rates according to the drought treatment and season. Correlation coefficient $\left(R^{2}\right)$ and slope (called "sl" afterwards) from Pearson's correlations between measured and modeled emissions were used to evaluate the algorithm $(L+T$ or $T)$ that better predicted $Q$. pubescens emissions under the different drought conditions and seasonal cycle. These correlations indicate whether there was an under- or overestimation of modeled emissions with $\mathrm{sl}<1$ and $\mathrm{sl}>1$, respectively, or whether the intercept (called $b$ hereafter) is different from 0 . For that, slope comparison tests were performed to check for slope significant differences from 1 and intercept tests were performed to check whether the intercept is significantly different from 0 . These correlations were obtained without forcing data to pass through the origin and with this relation: modeled emissions $=a \cdot$ measured emission $+b$. 
Table 1. Net photosynthesis $\left(\mathrm{Pn}, \mu \mathrm{molCO} 2 \mathrm{~m}^{-2} \mathrm{~s}^{-1}\right)$, stomatal conductance to water $\left(\mathrm{Gw}, \mathrm{mmolH}_{2} \mathrm{O} \mathrm{m}^{-2} \mathrm{~s}^{-1}\right)$ and emission rates $\left(\mu \mathrm{gCg} \mathrm{DM}^{-1} \mathrm{~h}^{-1}\right)$ according to treatment and season. Values represent an average of all data measured between 12:00 and 15:00 (local time). Letters denote the difference between drought treatments with $\mathrm{a}>\mathrm{b}$ and values showed represent the mean $\pm \mathrm{SE}, n=5$. ND is natural drought and AD is amplified drought with ns being non-significant, $(*)$ being $0.05<P<0.1$, $*$ being $0.01<P<0.05$ and $* *$ being $0.001<P<0.01$.

\begin{tabular}{|c|c|c|c|c|c|c|c|c|c|}
\hline \multirow{2}{*}{$\begin{array}{l}\text { Season } \\
\text { Treatments }\end{array}$} & \multicolumn{3}{|c|}{ Spring } & \multicolumn{3}{|c|}{ Summer } & \multicolumn{3}{|c|}{ Autumn } \\
\hline & ND & $\mathrm{AD}$ & $P$ & ND & $\mathrm{AD}$ & $P$ & ND & $\mathrm{AD}$ & $P$ \\
\hline Pn & $11 \pm 1 \mathrm{a}$ & $9 \pm 2 \mathrm{a}$ & ns & $14 \pm 2 \mathrm{a}$ & $9 \pm 1.2 \mathrm{~b}$ & $(*)$ & $7 \pm 1 \mathrm{a}$ & $9 \pm 1 \mathrm{a}$ & ns \\
\hline Gw & $110 \pm 19 \mathrm{a}$ & $57 \pm 13 b$ & $(*)$ & $285 \pm 38 \mathrm{a}$ & $126 \pm 17 b$ & $* *$ & $122 \pm 23 \mathrm{a}$ & $74 \pm 21 \mathrm{a}$ & ns \\
\hline Isoprene & $20 \pm 4 \mathrm{a}$ & $10 \pm 2 b$ & $*$ & $124 \pm 10 \mathrm{a}$ & $81 \pm 11 b$ & $*$ & $3 \pm 1 \mathrm{a}$ & $5 \pm 2 \mathrm{a}$ & ns \\
\hline MACR + MVK + ISOPOOH & $0.1 \pm 0.03 \mathrm{a}$ & $0.1 \pm 0.01 \mathrm{a}$ & $\mathrm{ns}$ & $0.4 \pm 0.1 \mathrm{a}$ & $0.2 \pm 0.02 b$ & $*$ & $0.04 \pm 0.01 \mathrm{a}$ & $0.1 \pm 0.01 \mathrm{a}$ & ns \\
\hline Methanol & $1 \pm 0.1 \mathrm{a}$ & $0.5 \pm 0.04 \mathrm{~b}$ & $*$ & $1 \pm 0.2 \mathrm{a}$ & $0.6 \pm 0.03 \mathrm{~b}$ & $*$ & $0.2 \pm 0.03 \mathrm{a}$ & $0.2 \pm 0.1 \mathrm{a}$ & $\mathrm{ns}$ \\
\hline Acetaldehyde & $1 \pm 0.4 \mathrm{a}$ & $1 \pm 0.3 \mathrm{a}$ & $\mathrm{ns}$ & $2 \pm 0.5 \mathrm{a}$ & $1 \pm 0.1 \mathrm{a}$ & ns & $1 \pm 0.3 \mathrm{a}$ & $1 \pm 0.3 \mathrm{a}$ & ns \\
\hline Acetone & $0.5 \pm 0.1 \mathrm{a}$ & $0.2 \pm 0.02 \mathrm{a}$ & ns & $1 \pm 0.2 \mathrm{a}$ & $0.5 \pm 0.04 \mathrm{~b}$ & $* *$ & $0.4 \pm 0.1 \mathrm{a}$ & $0.4 \pm 0.1 \mathrm{a}$ & ns \\
\hline Formaldehyde & $0.2 \pm 0.05 \mathrm{a}$ & $0.1 \pm 0.01 \mathrm{a}$ & ns & $0.4 \pm 0.1 \mathrm{a}$ & $0.1 \pm 0.02 \mathrm{~b}$ & $* *$ & $0.2 \pm 0.1 \mathrm{a}$ & $0.3 \pm 0.1 \mathrm{a}$ & ns \\
\hline
\end{tabular}

\section{Results and discussion}

\subsection{Ecophysiological parameters}

The physiology of $Q$. pubescens was slightly impacted by amplified drought over the whole study (Fig. 2), with a decrease of $\mathrm{Gw}$ under amplified drought compared to natural drought - ranging from $44 \%$ in spring $(P<0.1)$ to $55 \%$ in summer $(P<0.01$, Table 1$)$. In autumn, there was no significant difference between both treatments. Pn was only slightly reduced in summer by $36 \%(P<0.1)$ with no difference for the others season. Thus, the stomatal closure observed had a slight impact on carbon assimilation. Indeed, $Q$. pubescens has a high stem hydraulic efficiency (Nardini and Pitt, 1999) which compensates for stomatal closure since it allows the plant to use water more efficiently, thus maintaining Pn. Moreover, it must be noted that an increase of Pn was observed in autumn and could likely be attributed to autumnal rains. These results showed that the amplified drought artificially applied to $Q$. pubescens at $\mathrm{O}_{3} \mathrm{HP}$ led to a moderate drought for this species, based on a moderate reduction of the physiological performances (Niinemets, 2010).

\subsection{Effect of drought on BVOC emissions}

Emissions of all BVOCs followed during this experimentation were reduced under amplified drought compared to natural drought, especially in spring and summer (Table 1), except for acetaldehyde emissions. Indeed, acetaldehyde was not significantly different between both treatments probably due to a large variability of the data set. In autumn, for all BVOCs, there was no difference between both plots. The decrease of oxygenated BVOCs in spring and summer under amplified drought (e.g., methanol, MACR + MVK + ISOPOOH, formaldehyde, acetone) could be explained by stomatal closure in spring and summer under amplified drought since emissions of these compounds are strongly bound to $\mathrm{Gw}$ (Niinemets et al., 2004). Isoprene

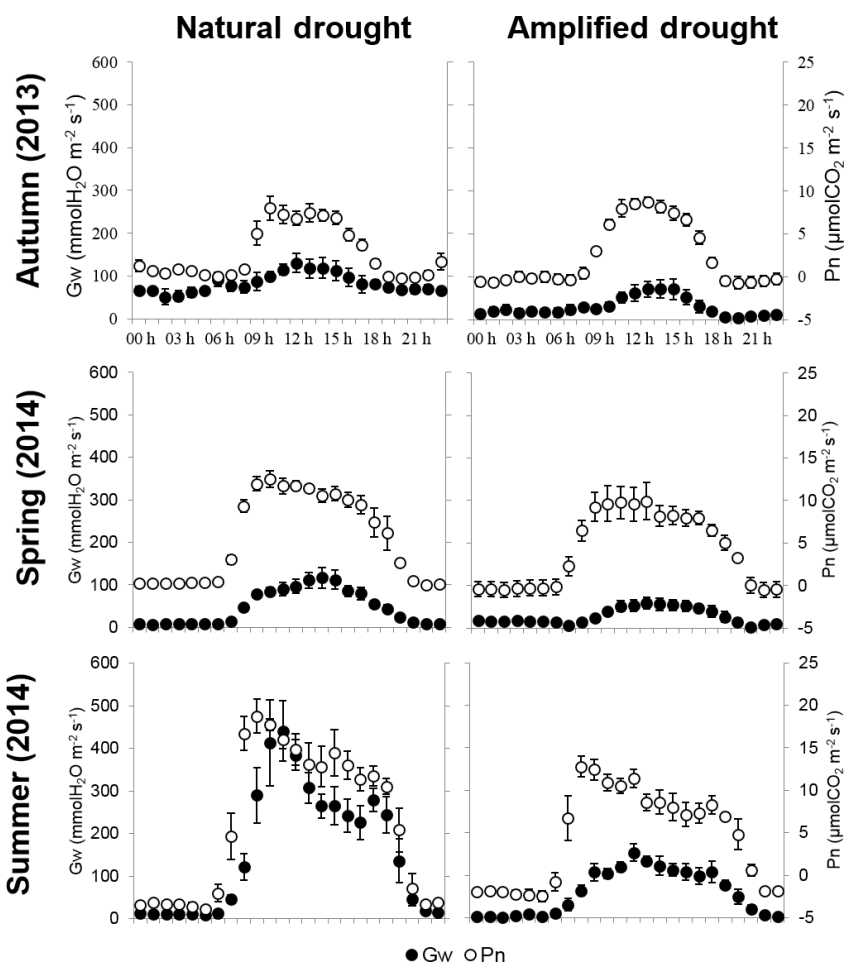

Figure 2. Diurnal pattern of stomatal conductance $(\mathrm{Gw})$ and net photosynthesis (Pn) according to drought treatment and season. Values showed represent means $\pm \mathrm{SE}, n=5$.

emissions were also reduced in spring and summer during the third year of this experiment whereas an increase had been observed in the first year. A decrease of isoprene emissions had already been shown by Brüggemann and Schnitzler (2002) but with potted plants. The isoprene decrease observed in our experiment cannot be explained by the stomatal closure because this compound could also be emitted through the cuticle (Sharkey and Yeh, 2001). It could rather be due to the decrease of $\mathrm{Pn}$, which reduced the carbon availability 

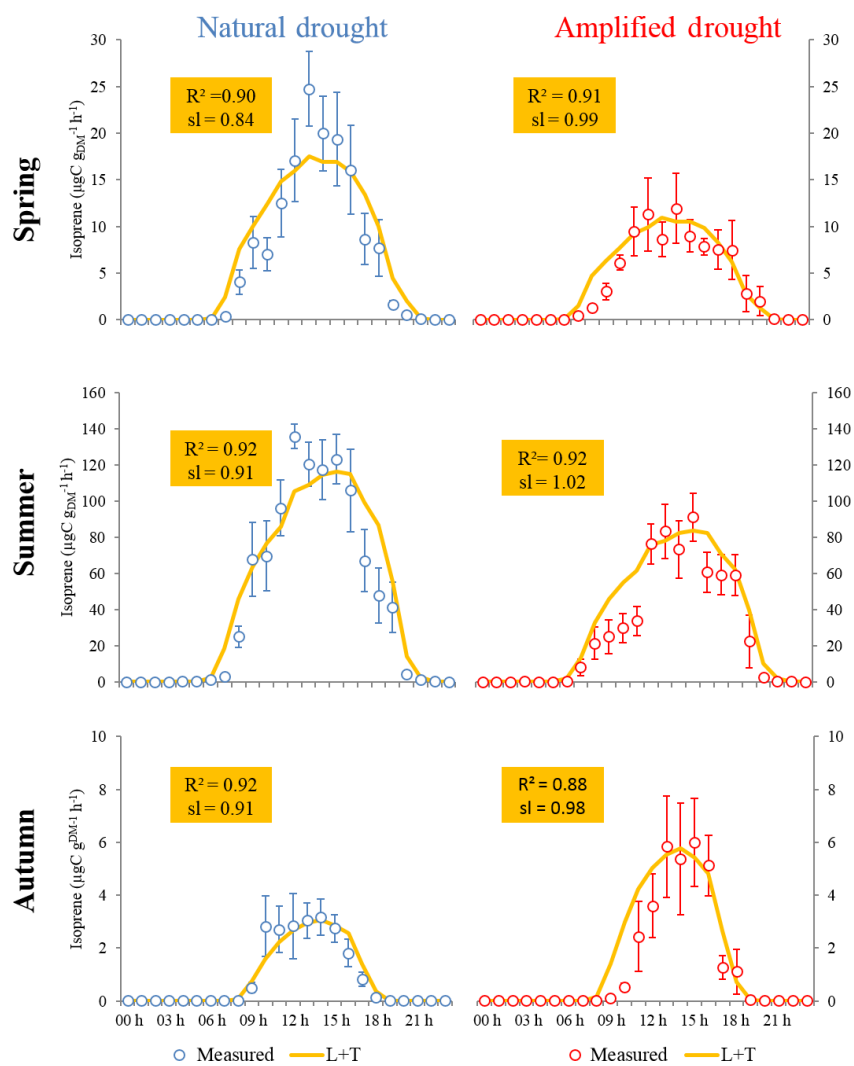

Figure 3. Diurnal pattern of isoprene emission rates, where points represent measured emission and the yellow line corresponds to modeled emission rates according to the $L+T$ algorithm $\left(\mathrm{ER}_{L+T}\right)$. $R^{2}$ and slope (sl) of correlations between measured ( $x$ axis) and modeled ( $y$ axis) emissions are presented in the yellow frame. Correlations were obtained without forcing data to pass through the origin. Values are mean $\pm \mathrm{SE}, n=5$.

to produce isoprene. Moreover, carbon assimilated through Pn can be also invested into the synthesis of other defense compounds, leading to a decrease of isoprene production and emission.

\subsection{Effect of drought on light and/or temperature dependency through a seasonal cycle}

All six BVOCs monitored showed daytime light and temperature dependencies (isoprene, degradation products of isoprene and acetaldehyde), while three BVOCs (methanol, acetone and formaldehyde) also showed emissions during the night despite the absence of light under constant temperature.

Regarding the light and temperature dependencies, the daily cycle of isoprene emissions (Fig. 3) showed that this compound clearly responds to light and temperature, as already known (Guenther et al., 1993), and that this response is not impacted by amplified drought. Isoprene can protect thylakoids from oxidative damage (Velikova et al., 2011) occurring mainly during the day, which can explain this
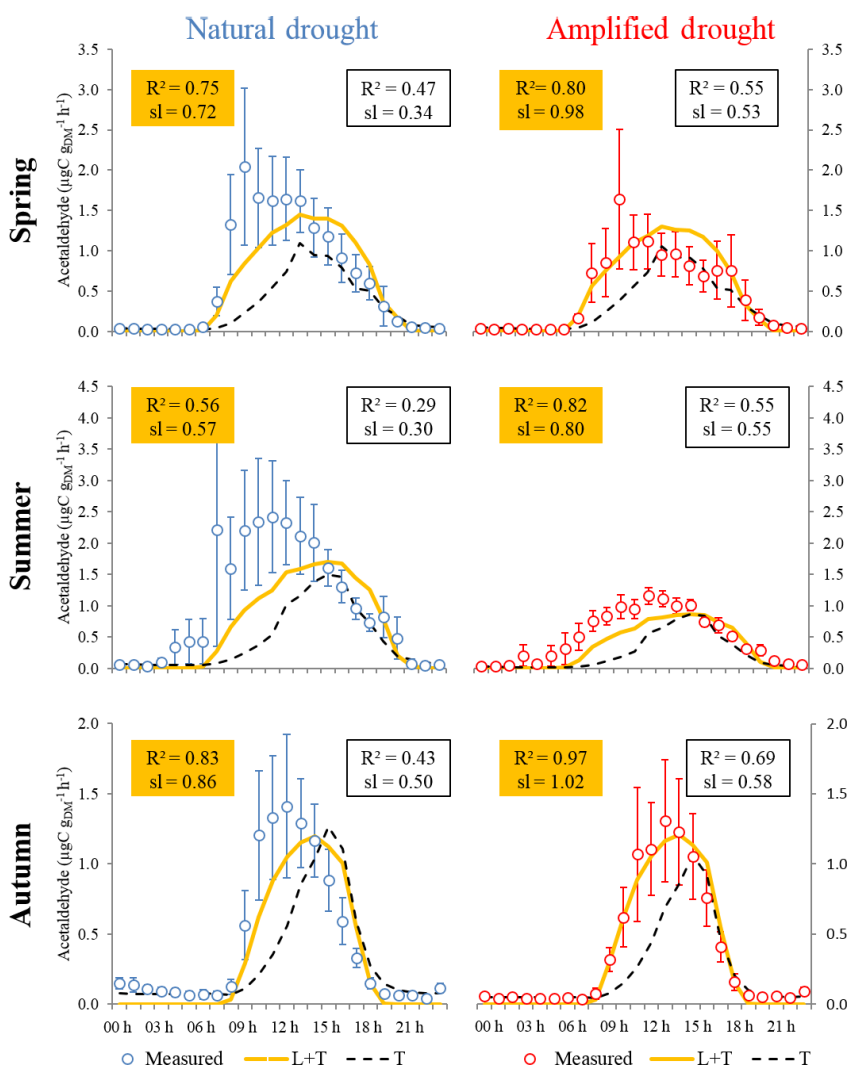

Figure 4. Diurnal pattern of acetaldehyde emission rates, where points represent measured emission, the yellow line corresponds to modeled emission rates according to the $L+T$ algorithm $\left(\mathrm{ER}_{L+T}\right)$ and the dotted line corresponds to modeled emission rates according to the $T$ algorithm $\left(\mathrm{ER}_{T}\right) \cdot R^{2}$ and slope ( $\mathrm{sl}$ ) of correlations between measured ( $x$ axis) and modeled ( $y$ axis) emissions are presented in the yellow frame for $L+T$ and in the white frame for $T$. Correlations were obtained without forcing data to pass through the origin. Values are mean $\pm \mathrm{SE}, n=5$.

kind of dependency. However, our results show the intensity of isoprene emission factor under natural and amplified drought is very different independently of the season. The modeled emissions were roughly representative of measured emissions. We note, however, that in spring, under natural drought, emissions were slightly underestimated $(\mathrm{s} l=0.84$, $P<0.05, R^{2}=0.90$ ). It suggests that although light and temperature remain the main factors driving isoprene emissions in spring, other parameters explain $10 \%$ of these emissions. At this season, plants likely needed to produce more isoprene to protect the establishment of photosynthetic machinery in the new leaves, which could slightly modify the effects of light and temperature on isoprene emissions.

MACR + MVK + ISOPOOH emissions, as isoprene, seemed to respond better to light and temperature than to only temperature (Fig. S2 in the Supplement) since correlations between measured emissions and $\mathrm{ER}_{L+T}$ were always better than correlations with $\mathrm{ER}_{T}$. Since 
$\mathrm{MACR}+\mathrm{MVK}+\mathrm{ISOPOOH}$ are oxidation products of isoprene (Oikawa and Lerdau, 2013), it is not surprising that these compounds followed the same pattern than isoprene in terms of dependency on light and temperature. The estimations of $\mathrm{ER}_{L+T}$ were quite good except in spring under natural drought where a slight underestimation was observed $(\mathrm{sl}=0.87, P<0.05)$. This underestimation can be explained by the underestimation of isoprene emissions observed at the same time since MACR + MVK + ISOPOOH comes from isoprene oxidation.

The dependency of acetaldehyde emissions on light and/or temperature is very contrasted; studies have shown that they are bound to both light and temperature (Jardine et al., 2008; Fares et al., 2011) or to temperature only (Hayward et al., 2004). Our results suggested that acetaldehyde emissions were mainly bound to light and temperature (Fig. 4). Indeed, correlations between measured and $\mathrm{ER}_{L+T}$ were always better than with $\mathrm{ER}_{T}$. However, some discrepancies were observed. Under natural drought, underestimations were observed in spring and summer $(\mathrm{sl}=0.72$ and $\mathrm{sl}=0.57$, $P<0.05$, respectively) whereas in autumn there was a good estimation ( $\mathrm{sl}=0.86, P>0.05)$. Under amplified drought, underestimation was only observed in summer $(\mathrm{sl}=0.80$, $P<0.05)$. Trees studied in this experiment did not show the same dependency on light and temperature of acetaldehyde emissions. $R^{2}$ of the correlation determining EF (performed tree by tree) varies from 0.34 to 0.90 in summer and from 0.67 to 0.92 in spring under natural drought. Under amplified drought, $R^{2}$ varies from 0.22 to 0.83 in summer (Table S6 in the Supplement). These results suggest that the effect of light and temperature on acetaldehyde emissions strongly depends on tree considered and could explain the underestimations observed in our experiment. Moreover, daily cycles of acetaldehyde emissions presented also an emission burst in the morning (at $7 \mathrm{~h}$, local time) in spring (under both treatments) and in summer (only under natural drought). Acetaldehyde can be produced due to an overflow of pyruvic acid during light-dark transitions. Cytosolic pyruvic acid levels rise rapidly and can be converted into acetaldehyde by pyruvate decarboxylase (Fall, 2003). This mechanism could explain the morning burst for this compound and the fact that no emissions during the night were observed.

We observed emissions of methanol, acetone and formaldehyde during the night under no light and constant temperature (around $20^{\circ} \mathrm{C}$, see Supplement S1). Correlations between $\mathrm{ER}_{L+T}$ or $\mathrm{ER}_{T}$ and measured methanol emissions were very similar, especially in spring and summer (Fig. 5). However, some observed phenomena suggested that methanol emissions were sustained by temperature in the absence of light. Indeed, the burst in the early morning (at $7 \mathrm{~h}$, local time), similar to acetaldehyde, was observed when stomata opened in spring and summer, independently of the drought treatment, although it was clearer under natural than amplified drought. This burst can be explained by a strong release of this compound that has been accumulated in the
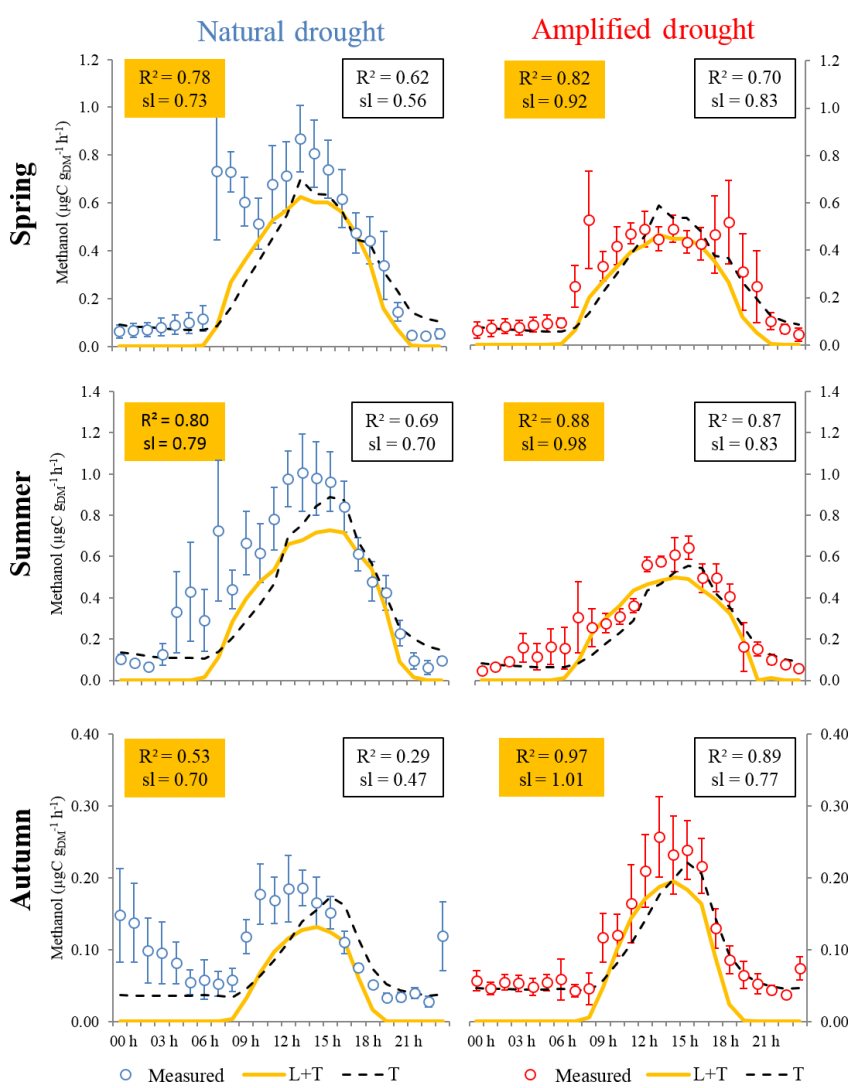

Figure 5. Diurnal pattern of measured methanol emission rates. Points represent measured emission, the yellow line corresponds to modeled emission rates according to the $L+T$ algorithm $\left(\mathrm{ER}_{L+T}\right)$ and the dotted line corresponds to modeled emission rates according to the $T$ algorithm $\left(\mathrm{ER}_{T}\right) \cdot R^{2}$ and slope (sl) of correlations between measured ( $x$ axis) and modeled ( $y$ axis) emissions are presented in the yellow frame for $L+T$ and in the white frame for $T$. Correlations were obtained without forcing data to pass through the origin. Values are mean $\pm \mathrm{SE}, n=5$.

intercellular air space and leaf liquid pools (due to the relative high polarity of methanol) at night when stomata are closed (Hüve et al., 2007). Moreover, for both drought treatments, methanol emissions during the night were observed at any seasons (especially autumn), which could be explained by nocturnal temperatures (roughly constant) that sufficed to maintain the biochemical processes involved in methanol formation. Methanol emissions, which result from the demethylation of pectin during the leaf elongation, have already been described as temperature-dependent alone (Hayward et al., 2004; Folkers et al., 2008). However, our results suggest that methanol emissions respond strongly to light and temperature during the day. This kind of diurnal emission cycle has already been described by Smiatek and Steinbrecher (2006). Our results of daily cycles of acetone emissions (Fig. S3 in the Supplement) showed that this compound responded better to light and temperature than only temperature since correlations were better with $\mathrm{ER}_{L+T}$. Un- 
der natural drought, the modeled emissions were well representative of measured emissions in summer. By contrast, in spring and in autumn, slight underestimations were observed ( $\mathrm{sl}=0.88, P<0.05$, and $\mathrm{sl}=0.69, P<0.05$, respectively). Under amplified drought, good estimations were observed in summer and autumn, but in spring there was an overestimation of modeled emissions ( $\mathrm{sl}=1.27, P<0.05)$. Previous studies have shown that acetone rather depends on temperature alone (Fares et al., 2011) or to light and temperature (Jacob et al., 2002), indicating that its dependency on light and/or temperature remains unclear. During the day, acetone emissions were dependent on light and temperature and emissions still occurred during the night, especially in autumn. Like methanol, nocturnal temperatures could allow us to maintain acetone formation (Smiatek and Steinbrecher, 2006). Acetone is a by-product of plant metabolism (Jacob et al., 2002) and its production can be enzymatic and nonenzymatic (Fall, 2003), which can explain these observed differences through the day. We can suppose that acetone emissions observed during the day could come from the enzymatic activity and, in contrast, during the night they could come from the non-enzymatic production.

Formaldehyde emissions followed the same pattern than methanol and acetone emissions (Fig. S4 in the Supplement), especially in autumn. By considering only the daytime (correlation with $L+T$ modeled emissions), there were good estimations in summer and autumn and a slight underestimation was observed in spring $(\mathrm{sl}=0.89, P<0.05)$ for natural drought. Under amplified drought, correlations indicated that $L+T$ modeled emissions were well representative of measured emissions, but some negative emissions were observed in summer, which suggested a deposition or an uptake of this compound by leaves as already highlighted by Seco et al. (2008). This phenomenon could have a role in stress tolerance, since formaldehyde can be catabolized (mainly through oxidations) within leaves, leading to $\mathrm{CO}_{2}$ formation (Oikawa and Lerdau, 2013). Emissions during the night suggest that formaldehyde came from a source other than oxidation within leaves since oxidation occurs mainly during the day due to an excess of light in chloroplasts, the principal place of reactive oxygen species production (Asada, 2006). Thus, formaldehyde emissions observed during the night could result from, for example, the glyoxylate decarboxylation or the dissociation of 5,10-methylene-THF (Oikawa and Lerdau, 2013). Predicting emission rates of these three compounds (methanol, acetone and formaldehyde) during the night seems to require other parameters such as a temperature threshold, below which methanol, acetone and formaldehyde synthesis and so emissions do not occur.

\section{Conclusion}

After 3 years of amplified drought, all BVOC emissions were reduced in spring and summer compared to natural drought whereas an increase was observed for some compounds in autumn. These results are in opposition to the results obtained after only 1 year of amplified drought (2012), especially for isoprene, where an increase was observed for this compound (Génard-Zielinski et al., 2017). Amplified drought did not seem to shift the dependency on light and/or temperature, which remained unchanged between treatments.

Moreover, two different dependent behaviors were found: (i) all six BVOCs monitored showed daytime light and temperature dependencies while (ii) only three BVOCs (methanol, acetone and formaldehyde) also showed that their emissions were maintained during the night with no light at rather constant nocturnal temperatures. Moreover, some phenomena, such as methanol and acetaldehyde emission bursts in early morning or the formaldehyde deposition/uptake (formaldehyde), were not assessed by either the $L+T$ or $T$ algorithm.

Data availability. Data can be found in the Supplement. 


\section{Appendix A: Calculation of ecophysiological parameters}

Net photosynthesis $\left(\mathrm{Pn}, \mu \mathrm{molCO} \mathrm{m}^{-2} \mathrm{~s}^{-1}\right)$ was calculated using equations described by Von Caemmerer and Farquhar (1981) as follows:

$\operatorname{Pn}=\frac{F \cdot\left(C_{\mathrm{r}}-C_{\mathrm{s}}\right)}{S}-C S \cdot E$.

$F$ is the inlet air flow $\left(\mathrm{mol} \mathrm{s}^{-1}\right), C_{s}$ and $C_{r}$ are the sample and reference $\mathrm{CO}_{2}$ molar fraction, respectively (ppm), $S$ is the leaf surface $\left(\mathrm{m}^{2}\right), C_{S} \cdot E$ is the fraction of $\mathrm{CO}_{2}$ diluted in water evapotranspiration and $E\left(\mathrm{molH}_{2} \mathrm{O} \mathrm{m}^{-2} \mathrm{~s}^{-1}\right.$ then transformed into $\mathrm{mmolH}_{2} \mathrm{O} \mathrm{m}^{-2} \mathrm{~s}^{-1}$ ) is the transpiration rate calculated as follows:

$E=\frac{F \cdot\left(W_{\mathrm{s}}-W_{\mathrm{r}}\right)}{S \cdot\left(1-W_{\mathrm{s}}\right)}$,

where $W_{\mathrm{s}}$ and $W_{\mathrm{r}}$ are the sample and the reference $\mathrm{H}_{2} \mathrm{O}$ molar fraction, respectively $\left(\mathrm{molH}_{2} \mathrm{O} \mathrm{mol}{ }^{-1}\right)$.

Stomatal conductance to water $\left(\mathrm{Gw}, \mathrm{molH}_{2} \mathrm{O} \mathrm{m}^{-2} \mathrm{~s}^{-1}\right.$ then transformed into $\mathrm{mmolH}_{2} \mathrm{O} \mathrm{m}^{-2} \mathrm{~s}^{-1}$ ) was calculated using the following equation:

$\mathrm{Gw}=\frac{E \cdot\left(1-\frac{W_{1}-W_{\mathrm{s}}}{2}\right)}{W_{1}-W_{\mathrm{s}}}$,

where $W_{1}$ is the molar concentration of water vapor within the leaf $\left(\mathrm{molH}_{2} \mathrm{O} \mathrm{mol}^{-1}\right)$ calculated as

$W_{1}=\frac{\mathrm{Vpsat}}{P}$,

where Vpsat is the saturated vapor pressure $(\mathrm{kPa})$ and $P$ was the atmospheric pressure $(\mathrm{kPa})$.

\section{Appendix B: Modeled emission calculation}

The modeled emission rates according to light and temperature $\left(\mathrm{ER}_{L+T}\right)$ or the temperature algorithm $\left(\mathrm{ER}_{T}\right)$ were calculated according to algorithms described in Guenther et al. (1995) as follows:

$\mathrm{ER}_{L+T}=\mathrm{EF}_{L+T} \cdot C_{l} \cdot C_{t}$

where $\mathrm{EF}_{L+T}$ is the emission factor at $1000 \mu \mathrm{mol} \mathrm{m}^{-2} \mathrm{~s}^{-1}$ of PAR and $30^{\circ} \mathrm{C}$ of temperature (obtained with the slope of the correlation between experimental emissions and $C_{l} \cdot C_{t}$ without forcing data to pass through the origin). $C_{l}$ and $C_{t}$ correspond to light and temperature dependency factors, respectively, and were calculated with the following formulae:

$C_{l}=\frac{\alpha C_{L 1} L}{\sqrt{1+\alpha^{2} L}}$

$C_{t}=\frac{\exp \frac{C_{T 1\left(T-T_{\mathrm{S}}\right)}}{R T_{\mathrm{S}} T}}{1+\exp \frac{C_{T 2}\left(T-T_{M}\right)}{R T_{\mathrm{S}} T}}$,

where $\alpha=0.0027, C_{L 1}=1.066, C_{T 1}=95000 \mathrm{~J} \mathrm{~mol}^{-1}$, $C_{T 2}=230000 \mathrm{~J} \mathrm{~mol}^{-1}, T_{M}=314 \mathrm{~K}$ are empirically derived constants. $L$ is the PAR flux ( $\left.\mu \mathrm{mol} \mathrm{m} \mathrm{m}^{-2} \mathrm{~s}^{-1}\right), T$ is the leaf experimental temperature $(\mathrm{K})$ and $T_{\mathrm{S}}$ is the leaf temperature at standard condition $(303 \mathrm{~K})$.

Modeled emissions according to temperature alone, i.e., $\mathrm{ER}_{T}$, were calculated as follows:

$\mathrm{ER}_{T}=\mathrm{EF}_{T} \cdot C_{T}$

where $\mathrm{EF}_{T}$ is the emission factor at $30^{\circ} \mathrm{C}$ (obtained with the slope of the correlation between experimental emissions and $C_{T}$ without forcing data to pass through the origin) and $C_{T}$ is a temperature-dependent factor calculated as

$C_{T}=\exp \left[\beta\left(T-T_{\mathrm{S}}\right)\right]$,

where $\beta$ is an empirical coefficient (with a standard variation value of $0.09 \mathrm{~K}^{-1}$ used in literature when not measured) determined, in this study, for each compound according to the season and the treatment through the slope of the correlation between the natural logarithm of measured emission rates (ER, $\mu \mathrm{gC} \mathrm{g}_{\mathrm{DM}}^{-1} \mathrm{~h}^{-1}$ ) and experimental temperature (expressed in $\mathrm{K}), T$ is the leaf experimental temperature $(\mathrm{K})$ and $T_{\mathrm{S}}$ is the standard temperature $(303 \mathrm{~K})$. 


\section{The Supplement related to this article is available online at https://doi.org/10.5194/acp-17-7555-2017-supplement.}

Author contributions. AS, EO and CF designed the research and the experimental design. AS, BTR, EO and CF conducted the research. AS, CB, BTR and CL collected and analyzed the data. AS, $\mathrm{EO}, \mathrm{CB}, \mathrm{HW}, \mathrm{BTR}, \mathrm{AA}$ and CF wrote the manuscript.

Competing interests. The authors declare that they have no conflict of interest.

Acknowledgements. This work was supported by the French National Agency for Research (ANR) through the SecPriMe ${ }^{2}$ project (ANR-12-BSV7-0016-01), Europe (FEDER) and ADEME/PACA for $\mathrm{PhD}$ funding. We are grateful to FR3098 ECCOREV for the $\mathrm{O}_{3} \mathrm{HP}$ facilities (https://o3hp.obs-hp.fr/index.php/fr/). We are very grateful to Jean-Philippe Orts and Ilja Reiter. We also thank all members of the DFME team from IMBE and particularly Stéphane Greff, Sylvie Dupouyet and Anne Bousquet-Melou for their help during measurements and analysis. We thank also the Université Paris Diderot for its support. The authors thank the MASSALYA instrumental platform (Aix-Marseille University, http://lce.univ-amu.fr) for the analysis and measurements used in this publication.

Edited by: Janne Rinne

Reviewed by: two anonymous referees

\section{References}

Arneth, A., Monson, R. K., Schurgers, G., Niinemets, Ü., and Palmer, P. I.: Why are estimates of global terrestrial isoprene emissions so similar (and why is this not so for monoterpenes)?, Atmos. Chem. Phys., 8, 4605-4620, https://doi.org/10.5194/acp8-4605-2008, 2008.

Asada, K.: Production and scavenging of reactive oxygen species in chloroplasts and their functions, Plant Physiol., 141, 391-396, 2006.

Beauchamp, J., Wisthaler, A., Hansel, A., Kleist, E., Miebach, M., Niinemets, Ü., Schurr, U., and Wildt, J.: Ozone induced emissions of biogenic VOC from tobacco: relationships between ozone uptake and emission of LOX products, Plant. Cell Environ., 28, 1334-1343, 2005.

Brüggemann, N. and Schnitzler, J. P.: Comparison of Isoprene Emission, Intercellular Isoprene Concentration and Photosynthetic Performance in Water-Limited Oak (Quercus pubescens Willd. and Quercus robur L.) Saplings, Plant Biol., 4, 456-463, 2002.

Cappellin, L., Karl, T., Probst, M., Ismailova, O., Winkler, P. M., Soukoulis, C., Aprea, E., Märk, T. D., Gasperi, F., and Biasioli, F.: On quantitative determination of volatile organic compound concentrations using proton transfer reaction time-of-flight mass spectrometry, Environ. Sci. Technol., 46, 2283-2290, 2012.

Dindorf, T., Kuhn, U., Ganzeveld, L., Schebeske, G., Ciccioli, P., Holzke, C., Köble, R., Seufert, G., and Kesselmeier,
J.: Significant light and temperature dependent monoterpene emissions from European beech (Fagus sylvatica L.) and their potential impact on the European volatile organic compound budget, J. Geophys. Res.-Atmos., 111, D16305, https://doi.org/10.1029/2005JD006751, 2006.

Fall, R.: Abundant oxygenates in the atmosphere: a biochemical perspective, Chem. Rev., 103, 4941-4952, 2003.

Fares, S., Gentner, D. R., Park, J.-H., Ormeno, E., Karlik, J., and Goldstein, A. H.: Biogenic emissions from Citrus species in California, Atmos. Environ., 45, 4557-4568, 2011.

Folkers, A., Hüve, K., Ammann, C., Dindorf, T., Kesselmeier, J., Kleist, E., Kuhn, U., Uerlings, R., and Wildt, J.: Methanol emissions from deciduous tree species: dependence on temperature and light intensity, Plant Biol., 10, 65-75, 2008.

Fortunati, A., Barta, C., Brilli, F., Centritto, M., Zimmer, I., Schnitzler, J. P., and Loreto, F.: Isoprene emission is not temperature dependent during and after severe drought stress: a physiological and biochemical analysis, Plant J., 55, 687-697, 2008.

Funk, J., Mak, J., and Lerdau, M.: Stress induced changes in carbon sources for isoprene production in Populus deltoides, Plant Cell Environ., 27, 747-755, 2004.

Genard-Zielinski, A.-C., Boissard, C., Fernandez, C., Kalogridis, C., Lathière, J., Gros, V., Bonnaire, N., and Ormeño, E.: Variability of BVOC emissions from a Mediterranean mixed forest in southern France with a focus on Quercus pubescens, Atmos. Chem. Phys., 15, 431-446, https://doi.org/10.5194/acp-15-4312015, 2015.

Genard-Zielinski, A.-C., Boissard, C., Ormeño, E., Lathière, J., Reiter, I. M., Wortham, H., Orts, J.-P., Temine-Roussel, B., Guenet, B., Bartsch, S., Gauquelin, T., and Fernandez, C.: Simulating precipitation decline under a Mediterranean deciduous Oak forest: effects on isoprene seasonal emissions and predictions under climatic scenarios, Biogeosciences Discuss., https://doi.org/10.5194/bg-2017-17, in review, 2017.

Giorgi, F. and Lionello, P.: Climate change projections for the Mediterranean region, Global Planet. Change, 63, 90-104, 2008.

Guenther, A., Hewitt, C. N., Erickson, D., Fall, R., Geron, C., Graedel, T., Harley, P., Klinger, L., Lerdau, M., McKay, W. A., Pierce, T., Scholes, B., Steinbrecher, R., Tallamraju, R., Taylor, J., and Zimmerman, P.: A global model of natural volatile organic compound emissions, J. Geophys. Res.-Atmos., 100, 8873-8892, 1995.

Guenther, A., Karl, T., Harley, P., Wiedinmyer, C., Palmer, P. I., and Geron, C.: Estimates of global terrestrial isoprene emissions using MEGAN (Model of Emissions of Gases and Aerosols from Nature), Atmos. Chem. Phys., 6, 3181-3210, https://doi.org/10.5194/acp-6-3181-2006, 2006.

Guenther, A. B., Jiang, X., Heald, C. L., Sakulyanontvittaya, T., Duhl, T., Emmons, L. K., and Wang, X.: The Model of Emissions of Gases and Aerosols from Nature version 2.1 (MEGAN2.1): an extended and updated framework for modeling biogenic emissions, Geosci. Model Dev., 5, 1471-1492, https://doi.org/10.5194/gmd-5-1471-2012, 2012.

Guenther, A. B., Zimmerman, P. R., Harley, P. C., Monson, R. K., and Fall, R.: Isoprene and monoterpene emission rate variability: model evaluations and sensitivity analyses, J. Geophys. Res.Atmos., 98, 12609-12617, 1993.

Hallquist, M., Wenger, J. C., Baltensperger, U., Rudich, Y., Simpson, D., Claeys, M., Dommen, J., Donahue, N. M., George, 
C., Goldstein, A. H., Hamilton, J. F., Herrmann, H., Hoffmann, T., Iinuma, Y., Jang, M., Jenkin, M. E., Jimenez, J. L., Kiendler-Scharr, A., Maenhaut, W., McFiggans, G., Mentel, Th. F., Monod, A., Prévôt, A. S. H., Seinfeld, J. H., Surratt, J. D., Szmigielski, R., and Wildt, J.: The formation, properties and impact of secondary organic aerosol: current and emerging issues, Atmos. Chem. Phys., 9, 5155-5236, https://doi.org/10.5194/acp9-5155-2009, 2009.

Harrison, S. P., Morfopoulos, C., Dani, K., Prentice, I. C., Arneth, A., Atwell, B. J., Barkley, M. P., Leishman, M. R., Loreto, F., and Medlyn, B. E.: Volatile isoprenoid emissions from plastid to planet, New Phytol., 197, 49-57, 2013.

Hayward, S., Tani, A., Owen, S. M., and Hewitt, C. N.: Online analysis of volatile organic compound emissions from Sitka spruce (Picea sitchensis), Tree Physiol., 24, 721-728, 2004.

Heikes, B. G., Chang, W., Pilson, M. E., Swift, E., Singh, H. B., Guenther, A., Jacob, D. J., Field, B. D., Fall, R., and Riemer, D.: Atmospheric methanol budget and ocean implication, Global Biogeochem. Cy., 16, 80-1-80-13, 2002.

Hüve, K., Christ, M., Kleist, E., Uerlings, R., Niinemets, Ü., Walter, A., and Wildt, J.: Simultaneous growth and emission measurements demonstrate an interactive control of methanol release by leaf expansion and stomata, J. Exp. Bot., 58, 1783-1793, 2007.

IPCC: Contribution of working group I to the fith assessment report of the intergovernmental panel on climate change, Cambridge Univeristy Press Cambridge, 2013.

Jacob, D. J., Field, B. D., Jin, E. M., Bey, I., Li, Q., Logan, J. A., Yantosca, R. M., and Singh, H. B.: Atmospheric budget of acetone, J. Geophys. Res.-Atmos., 107, ACH5-1-ACH5-17, 2002.

Jardine, K., Harley, P., Karl, T., Guenther, A., Lerdau, M., and Mak, J. E.: Plant physiological and environmental controls over the exchange of acetaldehyde between forest canopies and the atmosphere, Biogeosciences, 5, 1559-1572, https://doi.org/10.5194/bg-5-1559-2008, 2008.

Jimenez, J., Canagaratna, M., Donahue, N., Prevot, A., Zhang, Q., Kroll, J. H., DeCarlo, P. F., Allan, J. D., Coe, H., and Ng, N.: Evolution of organic aerosols in the atmosphere, Science, 326, 1525-1529, 2009.

Keenan, T., Niinemets, Ü., Sabate, S., Gracia, C., and Peñuelas, J.: Process based inventory of isoprenoid emissions from European forests: model comparisons, current knowledge and uncertainties, Atmos. Chem. Phys., 9, 4053-4076, https://doi.org/10.5194/acp-9-4053-2009, 2009.

Kesselmeier, J. and Staudt, M.: Biogenic volatile organic compounds (VOC): an overview on emission, physiology and ecology, J. Atmos. Chem., 33, 23-88, 1999.

Lippmann, M.: Health effects of ozone a critical review, Japca, 39, 672-695, 1989.

Liu, Y., Siekmann, F., Renard, P., El Zein, A., Salque, G., El Haddad, I., Temime-Roussel, B., Voisin, D., Thissen, R., and Monod, A.: Oligomer and SOA formation through aqueous phase photooxidation of methacrolein and methyl vinyl ketone, Atmos. Environ., 49, 123-129, 2012.

Menut, L., Bessagnet, B., Khvorostyanov, D., Beekmann, M., Blond, N., Colette, A., Coll, I., Curci, G., Foret, G., Hodzic, A., Mailler, S., Meleux, F., Monge, J.-L., Pison, I., Siour, G., Turquety, S., Valari, M., Vautard, R., and Vivanco, M. G.: CHIMERE 2013: a model for regional atmospheric composition modelling, Geosci. Model Dev., 6, 981-1028, https://doi.org/10.5194/gmd-6-981-2013, 2013.

Millet, D. B., Guenther, A., Siegel, D. A., Nelson, N. B., Singh, H. B., de Gouw, J. A., Warneke, C., Williams, J., Eerdekens, G., Sinha, V., Karl, T., Flocke, F., Apel, E., Riemer, D. D., Palmer, P. I., and Barkley, M.: Global atmospheric budget of acetaldehyde: 3-D model analysis and constraints from in-situ and satellite observations, Atmos. Chem. Phys., 10, 3405-3425, https://doi.org/10.5194/acp-10-3405-2010, 2010.

Monson, R. K., Trahan, N., Rosenstiel, T. N., Veres, P., Moore, D., Wilkinson, M., Norby, R. J., Volder, A., Tjoelker, M. G., and Briske, D. D.: Isoprene emission from terrestrial ecosystems in response to global change: minding the gap between models and observations, Philos. T. R. Soc. Lond. A, 365, 1677-1695, 2007.

Nardini, A. and Pitt, F.: Drought resistance of Quercus pubescens as a function of root hydraulic conductance, xylem embolism and hydraulic architecture, New Phytol., 143, 485-493, 1999.

Niinemets, Ü.: Mild versus severe stress and BVOCs: thresholds, priming and consequences, Trends Plant Sci., 15, 145-153, 2010.

Niinemets, Ü., Loreto, F., and Reichstein, M.: Physiological and physicochemical controls on foliar volatile organic compound emissions, Trends Plant Sci., 9, 180-186, 2004.

Oikawa, P. Y. and Lerdau, M. T.: Catabolism of volatile organic compounds influences plant survival, Trends Plant Sci., 18, 695703, 2013.

Ormeno, E., Goldstein, A., and Niinemets, Ü.: Extracting and trapping biogenic volatile organic compounds stored in plant species, TrAC-Trend, Anal. Chem., 30, 978-989, 2011.

Owen, S., Harley, P., Guenther, A., and Hewitt, C.: Light dependency of VOC emissions from selected Mediterranean plant species, Atmos. Environ., 36, 3147-3159, 2002.

Papiez, M. R., Potosnak, M. J., Goliff, W. S., Guenther, A. B., Matsunaga, S. N., and Stockwell, W. R.: The impacts of reactive terpene emissions from plants on air quality in Las Vegas, Nevada, Atmos. Environ., 43, 4109-4123, 2009.

Peñuelas, J. and Staudt, M.: BVOCs and global change, Trends Plant Sci., 15, 133-144, 2010.

Polade, S. D., Pierce, D. W., Cayan, D. R., Gershunov, A., and Dettinger, M. D.: The key role of dry days in changing regional climate and precipitation regimes, Scientific reports, 4, 4364, https://doi.org/10.1038/srep04364, 2014.

Pollmann, J., Ortega, J., and Helmig, D.: Analysis of atmospheric sesquiterpenes: Sampling losses and mitigation of ozone interferences, Environ. Sci. Technol., 39, 9620-9629, 2005.

Quézel, P. and Médail, F.: Ecologie et biogéographie des forêts du bassin méditerranéen, Elsevier, Paris, 2003.

Reig-Armiñana, J., Calatayud, V., Cerveró, J., García-Breijo, F., Ibars, A., and Sanz, M.: Effects of ozone on the foliar histology of the mastic plant (Pistacia lentiscus L.), Environ. Pollut., 132, 321-331, 2004.

Rinne, H., Guenther, A., Greenberg, J., and Harley, P.: Isoprene and monoterpene fluxes measured above Amazonian rainforest and their dependence on light and temperature, Atmos. Environ., 36, 2421-2426, 2002.

Seco, R., Penuelas, J., and Filella, I.: Formaldehyde emission and uptake by Mediterranean trees Quercus ilex and Pinus halepensis, Atmos. Environ., 42, 7907-7914, 2008.

Sharkey, T. D. and Yeh, S.: Isoprene emission from plants, Annu. Rev. Plant Biol., 52, 407-436, 2001. 
Singh, H., Chen, Y., Tabazadeh, A., Fukui, Y., Bey, I., Yantosca, R., Jacob, D., Arnold, F., Wohlfrom, K., and Atlas, E.: Distribution and fate of selected oxygenated organic species in the troposphere and lower stratosphere over the Atlantic, J. Geophys. Res.-Atmos., 105, 3795-3805, 2000.

Smiatek, G. and Steinbrecher, R.: Temporal and spatial variation of forest VOC emissions in Germany in the decade 1994-2003, Atmos. Environ., 40, 166-177, 2006.

Velikova, V., Várkonyi, Z., Szabó, M., Maslenkova, L., Nogues, I., Kovács, L., Peeva, V., Busheva, M., Garab, G., and Sharkey, T. D.: Increased thermostability of thylakoid membranes in isoprene-emitting leaves probed with three biophysical techniques, Plant Physiol., 157, 905-916, 2011.
Vlasenko, A., Macdonald, A. M., Sjostedt, S. J., and Abbatt, J. P. D.: Formaldehyde measurements by Proton transfer reaction Mass Spectrometry (PTR-MS): correction for humidity effects, Atmos. Meas. Tech., 3, 1055-1062, https://doi.org/10.5194/amt3-1055-2010, 2010.

Von Caemmerer, S. v. and Farquhar, G.: Some relationships between the biochemistry of photosynthesis and the gas exchange of leaves, Planta, 153, 376-387, 1981.

Xie, X., Shao, M., Liu, Y., Lu, S., Chang, C.-C., and Chen, Z.-M.: Estimate of initial isoprene contribution to ozone formation potential in Beijing, China, Atmos. Environ., 42, 6000-6010, 2008. 